\title{
Management of Curriculum and the organizing of Learning the Characters
}

\author{
Septuri $^{1}$, Riyuzen ${ }^{2}$ \\ $\left\{\right.$ septuri@radenintan.ac.id ${ }^{1}$, reyuzen@gmail.com $\left.{ }^{2}\right\}$ \\ ${ }^{1,2}$ Fakultas Tarbiyah dan Keguruan Universitas Islam Negeri Raden Intan Lampung, Indonesia
}

\begin{abstract}
The aims of this study, first: to describe the characteristics of the curriculum planning, sccond: to describe the characteristics of the learning the characters, and third to describe the characteristics of the monitoring and evaluation of character education curriculum. This is a qualitative study. The place of research in MI Al Fatah Al Muhajirun Natar Lampung Selatan Indonesia. Informant research principals and teachers. Collecting data using observations, interviews and documentation. Data validity is tested by triangulation. Analysis using data reduction, data presentation and conclusion. The results of this study are: Being in the form of KTSP planning, combined with local cultural wisdom. Span the 'hierarchy of character education materials in eight of love. Teachers use a contextual approach and applicable to children. Each end of the week, children's achievement and character development in the book recorded monitor character, and routine evaluation.
\end{abstract}

Keywords: Management, Curriculum, Learning, Character.

\section{Introduction}

Education is a necessity of human life throughout his life, both as individuals, social groups, and citizens of the nation and state. Through education that emphasizes the importance of character values and quality in the learning process, individuals with good character will be formed. With a good individual character will form a good society, and with a good character of the community, a good nation and state character will also be formed. A nation and state are considered big by other nations and nations if they have a strong and strong character of the nation and state[1]. The learning process is inseparable from the curriculum, for this, how do curriculum management and learning contain these character values?

One solution to answer these questions is to hold effective character education in schools, which involves all components of the school (principals, teachers, staff) and parents of students as good partners. To build partnerships between schools and parents requires a comprehensive and integrative approach, which leads to the development of effective character education management to establish synergistic and harmonious relationships.

To carry out this effective character education, the teacher's role is very important. In carrying out their duties as character educators, the teacher in implementing the learning process should pay attention to the principles of effective character learning, namely: (1) that learning requires the active participation of students (active learning), (2) that each child learns by and different speeds, and (3) that children can learn effectively when they are in a conducive classroom environment[2] . 
According to the observations of researchers, one of the basic educational institutions that have an interest in organizing character education is MI Al Fatah Al Muhajirun Natar, South Lampung. Character education developed at MI Al Fatah Al Muhajirun Natar, South Lampung is to address the phenomenon of moral decadence, by carrying out a mission to deliver students to become perfect human beings (insan kamil). Character education at MI Al Fatah Al Muhajirun Natar South Lampung aims to foster eight characters in a loving student, which includes; love of God and Apostles, love of parents and teachers, love of others, love of excellence, love of ourselves, love of science and technology, love of the natural surroundings, and love of nation and country.

Character education at MI Al Fatah Al Muhajirun Natar South Lampung uses a holistic approach, which is an approach that involves all members of the school community, namely students, teachers, principals and parents of students. All are mobilized for the development of student awareness, strategic programs, and school policies, classroom learning programs, and partnership programs with parents. Based on the description above, researchers conducted a study, about curriculum management and character learning to describe the characteristics of curriculum management and character learning in MI Al Fatah Al Muhajirun Natar, South Lampung.

\section{Research Methods}

This research is qualitative. This research uses an ethnographic approach. Ethnographic studies describe and interpret culture, social groups or systems. Although the meaning of culture is very broad, ethnographic studies are usually focused on patterns of activities, language, beliefs, rituals and ways of life[3]. The place of this research is MI Al Fatah Al Muhajirun Natar, South Lampung.

The form of data in this study in the form of words, attitudes, and actions, written sources and documents. Informants in this study include the principal, teachers, staff, students, and parents of students. Data collection uses non-participant observation, structured interviews, and documentation. Data validity was tested using triangulation of sources, methods, and time. Data analysis was performed by data reduction, display, verification, and conclusion.

\section{Research Results And Discussion}

\subsection{Characteristics Planning of Curriculum 2013 with Character Values}

The character education curriculum used is an enhanced Education Unit Level Curriculum or the 2013 curriculum combined with local cultural wisdom, at the school known as culture-based character education. The curriculum combination is following the opinion of Muslich which states that the SBC is developed following the conditions of the education unit, the potential and characteristics of the area, as well as the social culture of the local community and students[4].

The 2013 character education curriculum is a culture-based curriculum that contains a set of plans and arrangements that contain objectives, content and lesson material as well as for instructions for use as guidelines for organizing learning activities to achieve the goals of character education. The compilation of components of cultural-based character education curriculum is in accordance with the opinion of Hilda Taba that in the curriculum there are certain components, namely statements about goals and objectives, selection and organization 
of materials and lesson content, forms and teaching and learning activities and evaluations learning outcomes[5].

The distribution of learning materials in the 2013 character education curriculum is contained in annual and semester programs. The description of competencies and learning activities is contained in the syllabus and lesson plans. Assessment of children's character development is done using character observation sheets. Lexy J. Moeloeng argue that a program is not just a single activity that can be completed in a short time, but it is a continuous activity because it implements a policy[6]. Referring to the above opinion, the compilation of annual programs, semester programs, syllabi, lesson plans, and assessment instruments is certainly an interrelated system.

Research conducted by Chi-Ming states that character education programs exhibit general characteristics namely a focus on positive, diverse and integrated school culture, with systematic development and implementation strategies, and evaluation of research-based programs[7]. Therefore many people have adapted the characteristics of planning, implementation, and evaluation. The results of the above study are different from the results of research conducted by Hing-keung Ma which states that there is no moral education curriculum informal schools in Hong Kong. And research Nanis Winarni, describes that the form of character education curriculum planning is an Education Unit Level Curriculum combined with local wisdom[8]. The description of competencies and learning activities is contained in the syllabus and lesson plan. Assessment of children's character development is done using character observation sheets. Character education in schools is guided and directed directly by each class teacher and subject teacher.

In Indonesia, the teaching of character education is bound by subjects of religion, social sciences, humanities, and other subjects. Several educational programs focus on character education, namely religious education (for MI there are subjects of morality), citizenship education, and ethics education. And in each subject should contain the four core competencies (KI) in which describe the character that must be possessed by each student.

The similarity of the results of this study with previous research is that character education in schools is designed and carried out systematically and planned through the utilization of human resources and other resources to achieve the expected character education goals. This is following the opinion of Hasibuan which states that management is the science and art of regulating the process of utilizing human resources and other resources effectively and efficiently to achieve certain goals[9].

Another difference, compared to previous research, is that this study shows that the development of teachers in the 2013 curriculum as a character model for children is absolute and must be done to provide an example for children. In character education, the teacher has a very important role, because the opportunities for students in school/class are more with the teacher. This is consistent with the opinion of Hermawan, et al which states that educators occupy key and strategic positions in creating a conducive and pleasant learning atmosphere to direct students to achieve their goals optimally[10].

Meaning in 2013 curriculum character education, teachers must be models, examples and role models for students. Teacher development efforts are also carried out independently or take part in government programs through scientific meetings, discussions and reading relevant books. Educators are educational staff who have scientific qualifications as figures who must be able to set and implement active learning strategies for the achievement of learning objectives. 


\subsection{Characteristics of Organizing Learning with Character Values in the Curriculum 2013}

The implementation of character learning in the 2013 curriculum refers to the vision of character education outlined in the mission of character education. The basic characters that are developed/realized from the organization of character education are described in eight learning materials/contents. According to Budiningsih learning material in the curriculum is interpreted as material to be taught to students[11].

The character learning approach in the 2013 curriculum was created/compiled using a down to earth learning approach, which is a contextual and applicable approach for children. Learning media used in the form of pictorial stories, stories of the Apostles, friends and pious people. The character learning evaluation system is carried out by monitoring and reporting on the child's character development, carried out by the class teacher every day at the madrasa.

Parents also monitor children's behavior while at home by using the character observation sheet following the actual situation, and report it to the teacher at school, so that the child's behavior both at school and at home is always well monitored. The use of the media is following the opinion of Gagne and Briggs which states that the learning media implicitly includes tools that are physically used to convey the contents of teaching materials[12].

Some previous studies on the implementation of character education, among others: Research conducted by Michael Bamidele Adeyemi, et al., states that the implementation of character education is taught integrated through subjects such as mathematics, science, humanities, social sciences, law and so on[13].

Darby Thompson Sewell and Helen C. Hall in their research stated that: Character curriculums include 27 characters, namely courage, patriotism, citizenship, honesty, fairness, respect for others, kindness, cooperation, self-esteem, self-control , courtesy, compassion, tolerance, perseverance, generosity, punctuality, cleanliness, cheerfulness, school pride, respect for the environment, respect for the creator, patience, creativity, sportsmanship, loyalty, perseverance, and virtue. The character curriculum becomes part of the core quality of curriculum standards needed by elementary schools, secondary schools, and high schools[14].

The results of this study indicate that the management of character education is a structuring effort in the field of character education which is carried out through planning, organizing, actualizing, and controlling activities, and evaluating systematically and continuously to achieve the goals set effectively and efficiently. In its implementation character education management needs to be developed through certaisn patterns that are following the results of the analysis of readiness that is owned by existing institutions or schools.

Compared with previous research in this study it is known that in essence children already have a character or innate nature so that each time developing a child's character, the first thing to do is introduce the goodness (knowing the good) to children about various kinds of characters from cognitive aspects; such as what is meant by the type of character (love of Allah and the Apostle, love for parents and teachers, etc.), what are the benefits of doing that character, how to do it and get used to it, and the disadvantages of not doing that character.

The above statement is in line with the opinion of Hernowo which states that character is a very basic character, character, or things that exist in a person[15].

In the implementation of character education for students of Madrasah Ibtidaiyah (MI), delivered by $\mathrm{Mr} / \mathrm{Mrs}$ teachers in class and outside the classroom guided by the material that has been prepared concerning the basic character set by the school. The learning process developed is democratic, involving many students playing an active role in learning activities in schools. Learning democratically is intended to create a conducive atmosphere for the class 
so that the character develops mutual respect and respect for the differences of opinion of his friends, and does not impose his own will. In selecting class administrators, students themselves choose their classmates who are considered worthy of class management. This is in line with the opinion of Suyitno which states that learning is an effort to create a climate and service to the diverse abilities, potentials, interests, talents, and needs of students so that optimal interaction occurs between teachers and students as well as between students and participants students[16].

The development of partnerships with parents of students in the context of the success of children's character education has been done actively to synergize children's habits at school and home. In line with the findings of the study, Muslic revealed that learning does emphasize efforts to provide opportunities for students to perform moral acts, both individually and together in a group[17].

The meaning of character learning in the 2013 curriculum through habituation activities carried out at school will become stronger if it is continued and familiarized at home with optimal supervision from parents. Good habits that have occurred at school will weaken and even disappear if at home does not get good support from parents, especially when there are rejection and opposition from family members at home.

\subsection{Characteristics of Monitoring and Evaluation Curriculum 2013 with Character Values}

Monitoring and evaluation of the 2013 character education curriculum were carried out using supervision techniques. The results showed an evaluation of the implementation of the curriculum has not been done by the school because the implementation of new character education has not been completed one semester.

The 2013 character education curriculum has a broad dimension because it covers many things and becomes a unified whole, as revealed by Sukmadinata that aspects of curriculum activities starting from planning, component development, implementation and learning outcomes are considered as the scope curriculum evaluation studies[18].

Research conducted by Baoren Suthat c haracter education is a social project that is systematic, large and complex education projects[19]. Therefore, the American government strengthens macroscopic regulation and supervision for character education. Further in his research explained that in education and American culture, the function of the teacher is to help students to make self-realization and gain knowledge and skills in their learning process. American teachers will not be involved and help design students' future lives, but they will play the role of student mentors, pay attention to students everyday learning problems, and offer help and advice for them.

The similarity of the results of the research with the journal, that is, the role of the principal's organizer in terms of organizing and dividing tasks into all components so that the implementation of character education runs effectively and efficiently. In carrying out their role as activators of character education, the principal always encourages all components to continue to carry out their respective duties for the successful formation of children's character. While its role as a controller has been seen in routine evaluation activities carried out by the principal to see the effectiveness of the implementation of character education.

Compared with previous research in this study, it is known that the meaning of the example of the principal for the teacher in the school is demonstrated by his discipline in every activity. Directing and encouraging non-stop (on various occasions) is always delivered to move the teacher and students in accustom good behavior. The principal as a controller of the success of character education in schools has been seen in routine evaluation activities 
carried out by the principal, where monthly reporting activities in the form of character education accountability reports continue to be carried out continuously, ie every month.

\section{Conclusions}

The form of character education curriculum planning is the Education Unit Level Curriculum which is combined with the wisdom of the local culture. The description of competencies and learning activities is contained in the syllabus and lesson plan. Assessment of children's character development is done using character observation sheets. Character education in schools is guided and directed directly by each class teacher and subject teacher. The character education content is described in the subject matter as the embodiment of the four core competencies.

Learning methods use a contextual and applicable approach for children. The achievements and character development of children are monitored weekly which is published in the children's portfolio book, which is filled in by the class teacher based on observation sheets provided by the subject teacher and students' parents. Routine evaluations are carried out by the principal, in monthly reporting activities and at the end of each semester.

\section{References}

[1] D. Rosyada, Paradigma Pendidikan Demokratis. Jakarta: Kencana Prenada, 2007.

[2] Megawangi, Character Parenting Space; Menjadi Orang Tua Cerdas Untuk Membangun Karater Anak. Bandung: Publising House, 2007.

[3] N. S. Sukmadinata, Metode Penelitian Pendidikan. Bandung: Remaja Rosda Karya, 2006.

[4] M. Muslich, Kurikulum Tingkat Satuan Pendidikan, Dasar Pemahaman dan Pengembangan, Pedoman Bagi Pengelola Lembaga Pendidikan, Pengawas Sekolah, Kepala Sekolah, Komite Sekolah, Dewan Sekolah, dan Guru. Jakarta: Bumi Aksara, 2007.

[5] S. Nasution, Asas-Asas Kurikulum. Jakarta: Bumi Aksara, 2007.

[6] Moleong Lexy J, Metodologi Penelitian Kualitatif. Bandung: Remaja Rosdakarya, 2004.

[7] C. M. A. Lee, "The planning, implementation and evaluation of a character-based school culture project in Taiwan," J. Moral Educ., vol. 38, no. 2, pp. 165-184, 2009.

[8] N. Winarni, "Manajemen Kurikulum Dan Pembelajaran Bermuatan Nilai -Nilai Karakter Di Sekolah Dasar," Program Pascasarjana Universitas Muhammadiyah Surakarta, 2014.

[9] S. Hasibuan, Malayu, Manajemen: Dasar, Pengertian dan Masalah. Jakarta: Bumi Aksara, 2009.

[10] A. . dkk Hermawan, Pengembangan Kurikulum dan Pembelajaran. Jakarta: Universitas Terbuka, 2008.

[11] A. Arsyad, Media Pembelajaran. Jakarta: PT. Raja Grafindo Persada, 2011.

[12] A. Arsyad, Media Pembelajaran. Jakarta: PT. Raja Grafindo Persada, 2011.

[13] M. B. Adeyemi, T. V. Moumakwa, and D. A. Adeyemi, "Teaching Character Education Across the Curriculum and the Role of Stakeholders at the Junior Secondary Level in Botswana," Stud. Home Community Sci., vol. 3, no. 2, pp. 97-105, 2009.

[14] D. T. Sewell and H. C. Hall, "Teachers' Attitudes Toward Character Education and 
Inclusion in Family and Consumer Sciences Education Curriculum," vol. 21, no. 1, pp. 11-17, 2003.

[15] H. Suharsaputra, Administrasi Pendidikan. Bandung: Refika Aditama, 2010.

[16] Suyitno, Penilaian Kurikulum 2013 Membantu Guru dan Calon Guru Mengetahui Langkah-langkah Penilaian Pembelajaran. Yogyakarta: Andi, 2014.

[17] M. Muslich, Kurikulum Tingkat Satuan Pendidikan, Dasar Pemahaman dan Pengembangan, Pedoman Bagi Pengelola Lembaga Pendidikan, Pengawas Sekolah, Kepala Sekolah, Komite Sekolah, Dewan Sekolah, dan Guru. Jakarta: Bumi Aksara, 2007.

[18] N. S. Sukmadinata, Prinsip dan Landasan Pengembangan Kurikulum. Bandung: Remaja Rosda Karya, 2007.

[19] B. Su, "A Comparison and Research on the Sino-U.S Bilingual Education," Asian Soc. Sci., vol. 5, no. 8, pp. 111-115, 2009. 